\title{
Penggunaan Boron untuk Meningkatkan Pertumbuhan, Hasil, dan Kandungan Minyak Kacang Tanah
}

\author{
Boron for Promoting Growth, Production, and Fat in the Ground Nut
}

\author{
Hermawan Sugianto ${ }^{1)}$, Linayanti Darsana ${ }^{2)}$, Pardono ${ }^{2)}$
}

\begin{abstract}
Ground nut (Arachis hypogaea) is a seasonal crop that have been cultured in many place as for interspace crop or as monoculture crop. Though the demand of ground nut is high, its yield productivity not optimal and still considerate as moderate. Therefore, a new treatment is needed. Boron is one of essensial nutrition for plant that rarely used when planting, although boron have many function including to increase plant productivity. This research is purposed to see about boron influence in the ground nut productivity and fat contain on it. The result of the research showed boron can increase the flowering time of ground nut. The result of ground nut productivity not shown any significant differences, but inclined to had increased productivity up to $20 \%$ than control in $5 \mathrm{mg} \mathrm{B2O} 3$ dosage and keep decreasing as the boron dosage increased. Boron also have real influence in increasing the ground nut seed quality with the increased of gound nut weight, and the calculation of fat contain in ground nut that also increased as the boron dosage increased.
\end{abstract}

Keywords : boron, fat, ground nut

\section{PENDAHULUAN}

Kacang tanah termasuk tanaman yang sangat populer di Indonesia. Kepopuleran kacang tanah tak lepas dari berbagai manfaat yang diberikannya. Kacang tanah dapat digunakan dalam berbagai olahan baik konsumsi sebagai sumber protein nabati, maupun kosmetik dan obat-obatan. Kacang tanah juga memiliki kandungan minyak yang cukup besar dan kerapkali diekstrak untuk diambil minyaknya. Sebagai tanaman yang sangat diminati dan diperlukan, kacang tanah memiliki kendala di mana produksinya belum mencapai target maksimal. Ratarata produksi kacang tanah di Indonesia tergolong menengah yaitu berkisar 17 ton ha ${ }^{-1}$ pada tahun 2013 (BPS), sementara pada beberapa daerah produksi kacang tanah mampu mencapai angka 21 ton $\mathrm{ha}^{-1}$. Artinya banyak daerah di Indonesia yang masih memiliki produksi dibawah potensi hasil yang ada. Hal ini menunjukan perlu dilakukan suatu solusi baru terhadap penanaman kacang tanah agar dapat memacu produksinya menjadi lebih tinggi ketika intensifikasi pemupukan N, P, K saja sudah tidak dapat meningkatkan hasil produksi dari kacang tanah.

Menurut Mattielo (2009) boron jumlahnya sangat terbatas di dalam tanah terutama pada jenis-jenis tanah tropis, sementara boron merupakan salah satu unsur yang berperan dalam meningkatkan hasil produksi suatu tanaman. Ketersediaan boron juga terikat pada tanah sehingga jumlah yang tersedia sangat terbatas bagi tanaman. Hal ini merupakan

\footnotetext{
1) Undergraduate Student of Study Program of Agrotechnology, Faculty of Agriculture, University of Sebelas Maret (UNS) in Surakarta.

2) Lecturer of Study Program of Agrotechnology, Faculty of Agriculture, University of Sebelas Maret (UNS) in Surakarta.
}

sebuah kendala mengingat minimnya ketersediaan boron di dalam tanah tidak diimbangi dengan pemupukan boron. Hal ini menunjukan bahwa boron berkemungkinan memiliki kemampuan dalam meningkatkan hasil produksi kacang tanah yang selama ini kurang dapat optimal. Penelitian kali ini dilakukan untuk melihat ada tidaknya pengaruh dari boron dalam meningkatkan pertumbuhan, produksi, dan kandungan minyak dari tanaman kacang tanah.

\section{METODE PENELITIAN}

Penelitian ini dilakukan di Rumah Kaca, Fakultas Pertanian, Universitas Sebelas Maret, Surakarta. Penelitian dilakukan pada bulan Februari hingga Juli 2014. Kacang tanah yang diteliti ditanam pada polybag-polybag ukuran diameter $30 \mathrm{~cm}$ yang telah diberi campuran tanah dan bahan organik sebanyak $3 \mathrm{~kg}$ atau kurang lebih 3/4 polybag. Boron dalam bentuk $\mathrm{B}_{2} \mathrm{O}_{3}$ kemudian diaplikasikan pada tanaman uji dengan dosis $0 \mathrm{mg}$ (kontrol), $5 \mathrm{mg}$ (A1), $10 \mathrm{mg}$ (A2), dan $20 \mathrm{mg}$ (A3) sebanyak 2 kali, yaitu ketika tanaman uji berumur 2 minggu setelah tanam (MST), dan setelah $80 \%$ tanaman sudah berbunga. Pemberian boron pertama ditujukan untuk melihat pengaruh boron terhadap fase vegetatif tanaman, sementara aplikasi kedua untuk melihat pengaruh boron pada tingkat generatif tanaman.

Pengamatan yang dilakukan untuk fase vegetatif adalah tinggi tanaman dan jumlah daun tanaman yang diukur setiap satu minggu sekali, serta berat brangkasan yang diukur saat tanaman uji selesai dipanen. Hasil fase generatif didapat pada 12 MST ketika tanaman dipanen. Pengukuran dilakukan meliputi hasil polong, berat 100 biji, serta kandungan lemak/ minyak yang ada didalam biji kacang tanah yang dianalisis menggunakan metode soxhlet.

Contact Author: linayanti_darsana@yahoo.com

Penggunaan Boron untuk Meningkatkan Pertumbuhan, Hasil, dan Kandungan Minyak Kacang Tanah

Hermawan Sugianto, Linayanti Darsana, Pardono 


\section{HASIL DAN PEMBAHASAN}

\section{Tinggi Tanaman}

Hasil pertumbuhan tanaman kacang tanah (Tabel 1) menunjukan bahwa boron belum berpengaruh nyata terhadap pertumbuhan tanaman kacang berdasarkan aspek tinggi tanamannya. Hal ini terlihat dengan hasil analisis data dimana tidak ada perlakuan yang memberikan hasil beda nyata terhadap tinggi kacang tanah. Kurang nyatanya pengaruh boron terhadap pertumbuhan kemungkinan disebabkan oleh minimnya nutrisi pendukung pertumbuhan seperti pupuk nitrogen. Boron mampu meningkatkan tingkat penyerapan hara oleh tanaman (Matas et al. 2009), namun ketika ketersediaan nutrisi juga minim maka hara yang terserap menjadi terbatas. Hal tersebut kemungkinan yang menjadi penyebab mengapa pertumbuhan tanaman tidak terlihat dipengaruhi secara nyata oleh aplikasi dari B2O3.

Tabel 1. Tinggi tanaman kacang tanah

\begin{tabular}{ccccccc}
\hline Perlakuan & I & II & III & IV & V & Rata-rata \\
\hline A0 & 69,96 & 64,86 & 68,05 & 62,80 & 62,33 & $65,60 \mathrm{ab}$ \\
A1 & 65,13 & 58,36 & 70,06 & 58,05 & 58,03 & $61,93 \mathrm{a}$ \\
A2 & 69,95 & 64,35 & 65,23 & 68,30 & 60,50 & $65,66 \mathrm{ab}$ \\
A3 & 70,80 & 61,60 & 60,93 & 65,60 & 53,50 & $62,48 \mathrm{ab}$ \\
\hline
\end{tabular}

\section{Jumlah Daun}

Daun merupakan organ tanaman yang berperan aktif dalam melakukan fotosintesis. Daun sedikit banyak dapat digunakan untuk melihat baik buruknya kondisi suatu tanaman. hasil penghitungan jumlah daun tanaman kacang tanah (Tabel 2) masih belum memberikan hasil signifikan. Hasil dari antar perlakuan nyaris sama, dengan rata-rata jumlah daun yang tidak terpaut jauh. Hasil tersebut sama seperti hasil yang diperoleh dari tinggi tanaman dimana boron belum dapat menunjukan peran dalam meningkatkan kualitas pertumbuhan tanaman. $\mathrm{Hal}$ ini juga memperlihatkan adanya sinergi antara tinggi tanaman maupun jumlah daun. Dimana keduanya adalah bagian dari pertumbuhan vegetatif tanaman dan keduanya sama-sama belum terpengaruh oleh aplikasi dari boron.

Tabel 2. Jumlah daun kacang tanah

Taber. Jumah daun kacang anah

\begin{tabular}{ccccccc}
\hline Perlakuan & I & II & III & IV & V & Rata-rata \\
\hline A0 & 33 & 27 & 29 & 29 & 31 & $29.8 \mathrm{ab}$ \\
A1 & 32 & 31 & 32 & 31 & 30 & $31.2 \mathrm{ab}$ \\
A2 & 29 & 29 & 33 & 34 & 32 & $31.4 \mathrm{ab}$ \\
A3 & 31 & 30 & 34 & 32 & 21 & $29.6 \mathrm{a}$ \\
\hline
\end{tabular}



Gambar 1. Persentase tanaman berbunga minggu ke-4 


\section{Berat Segar dan Kering Brangkasan}

Hasil dari berat segar brangkasan berbanding lurus dengan tinggi tanaman, di mana semakin tinggi suatu tanaman kacang tanah maka semakin besar berat segarnya seperti yang terlihat pada Tabel 3 . Pada tanaman dengan perlakuan A3 berat segar mengalami penurunan jika dibandingkan dengan perlakuan lainnya. Serangan hama di akhir waktu penanaman menjadi faktor utama penyebab penurunan berat segar tanaman uji A3. Hasil analisis data terlihat adanya perbedaan nyata dalam pengukuran berat segar tanaman.

Analisis lanjutan menggunakan uji DMRT taraf 5\% menunjukan adanya beda nyata pada perlakuan 20 $\mathrm{mg} \mathrm{B}_{2} \mathrm{O}_{3}$. Terjadinya penurunan berat segar mutlak terjadi oleh karena serangan hama. Kemungkinan yang dapat diperkirakan kenapa intensitas serangan banyak terjadi pada perlakuan $\mathrm{A} 3$ adalah tingginya dosis boron menyebabkan penyerapan hara menjadi lebih besar (Mattas et al. 2009) jika dibandingkan dengan perlakuan $\mathrm{A} 0, \mathrm{~A} 1$, dan $\mathrm{A} 2$ yang dosis $\mathrm{B}_{2} \mathrm{O}_{3}$ nya lebih rendah. Tingginya tingkat penyerapan hara memungkinkan jaringan yang ada pada tanaman menjadi lebih lunak jika dibandingkan pada tanamantanaman dengan serapan hara yang rendah. Hal inilah yang akhirnya membuat serangan hama menjadi lebih intens terjadi pada tanaman-tanaman dengan perlakuan dosis boron terbesar yaitu perlakuan A3.

Hal lain yang kemungkinan dapat terjadi adalah sifat boron yang mampu mempercepat metabolisme sehingga dapat mempersingkat waktu tanam. Hal ini juga terlihat pada waktu pembungaan dimana semua perlakuan dengan pemberian boron terlihat memiliki waktu berbunga yang lebih singkat. Semakin besar dosis boron maka berkemungkinan membuat umur tanaman semusim menjadi lebih pendek. Ketika tanaman mendekati masa akhir hidupnya maka jaringan tanaman menjadi lebih lemah dan lebih rentan terserang hama. Rentannya tanaman terserang karena tanaman tidak lagi memperbaiki jaringan-jaringan yang rusak seoptimal ketika masamasa vegetatif. Hal inilah yang menjadikan serangan hama di akhir masa tanam lebih besar terjadi justru pada perlakuan dengan dosis perlakuan tertinggi, karena dosis boron tertinggi memungkinkan waktu tanam yang lebih pendek dibandingkan dosis A0, A1, dan A2.

Sama seperti pengukuran berat segar tanaman, penyebab terbesar terjadinya penurunan berat kering pada tanaman uji A3 yaitu oleh serangan hama (Tabel 4). Serangan hama membuat beberapa tanaman uji menjadi kering dan beberapa bagian daunnya berguguran. Hal inilah yang diperkirakan menjadi penyebab utama mengapa berat kering tanaman uji A3 menjadi sedikit lebih rendah jika dibandingkan perlakuan lainnya. Apabila melihat rentang berat antar perlakuan, maka jarak A3 dengan perlakuan lainnya tidak sebesar ketika mengukur berat segar tanaman. Angka tersebut menunjukan serangan hama berpengaruh terhadap kandungan air dalam jaringan tanaman. Hama menyerang tanaman dengan menghambat metabolisme tanaman, menyerap kandungan air didalam jaringan dan membuat tanaman menjadi kering, sementara boron yang diberikan masih belum berpengaruh nyata pada berat kering tanaman.

Tabel 3. Berat segar tanaman

\begin{tabular}{ccccccc}
\hline Perlakuan & I & II & III & IV & V & Rata-rata \\
\hline A0 & 48,51 & 37,86 & 44,69 & 40,90 & 45,43 & 43.48 bc \\
A1 & 45,93 & 38,07 & 42,36 & 42,68 & 44,60 & $42.73 \mathrm{~b}$ \\
A2 & 54,54 & 44,09 & 43,39 & 47,87 & 33,72 & $44.72 \mathrm{bc}$ \\
A3 & 39,52 & 33,59 & 37,86 & 36,50 & 28,18 & $35.13 \mathrm{a}$ \\
\hline
\end{tabular}

Tabel 4. Berat kering tanaman

\begin{tabular}{ccccccc}
\hline Perlakuan & I & II & III & IV & V & Rata-rata \\
\hline A0 & 11,31 & 8,31 & 10,93 & 9,87 & 10,76 & $10,23 \mathrm{ab}$ \\
A1 & 10,19 & 9,50 & 9,74 & 10,20 & 11,04 & $10,13 \mathrm{ab}$ \\
A2 & 11,98 & 11,31 & 9,91 & 11,27 & 8,55 & $10,60 \mathrm{ab}$ \\
A3 & 9,83 & 9,15 & 10,07 & 9,10 & 7,55 & $9,14 \mathrm{a}$ \\
\hline
\end{tabular}

\section{Berat Polong}

Kadar hasil produksi tanaman kacang tanah umumnya sangat dipengaruhi oleh berbagai hal seperti baik buruknya kondisi tanaman, ketersediaan unsur hara dan nutrisi tanaman, kondisi lahan, ketersediaan air, dan lain sebagainya. Hasil penimbangan polong kacang tanah seperti yang terlihat pada Tabel 5, belum menunjukan adanya beda nyata menurut analisis ragam. Meski demikian hasil yang didapatkan menunjukan A1 cenderung jauh lebih besar jika dibandingkan dengan perlakuan lainnya. Jika dibandingkan dengan hasil kontrol (A0), hasil dari A1 lebih besar 17,8 gr atau sekitar $21 \%$ lebih tinggi dari hasil kontrol. Sementara seluruh perlakuan dengan pemberian boron menunjukan hasil diatas kontrol. Perolehan model hasil seperti ini 
hampir serupa dengan hasil yang didapat oleh Moura kelapa sawit yang ditambahkan boron. et al, 2013 dalam penelitiannya terhadap tanaman

Tabel 5. Berat polong kacang tanah

\begin{tabular}{lcccccc}
\hline Perlakuan & I & II & III & IV & V & Jumlah \\
\hline A0 & 15,74 & 16,01 & 16,65 & 16,94 & 19,73 & $85,07 \mathrm{a}$ \\
A1 & 20,27 & 19,58 & 20,71 & 24,03 & 18,34 & $102,93 \mathrm{~b}$ \\
A2 & 20,13 & 17,57 & 16,15 & 19,64 & 15,46 & $88,95 \mathrm{ab}$ \\
A3 & 15,85 & 15,89 & 23,02 & 17,71 & 14,08 & $86,55 \mathrm{ab}$ \\
Jumlah & 71,99 & 69,05 & 76,53 & 78,32 & 67,61 & 363,50 \\
\hline
\end{tabular}

\section{Berat 100 Biji}

Penghitungan berat 100 biji menunjukan bahwa boron mampu meningkatkan kualitas dari hasil tanaman. Uji DMRT menunjukan beda nyata di semua perlakuan dengan penambahan $\mathrm{B}_{2} \mathrm{O}_{3}$. Hal tersebut kemungkinan merupakan hasil dari kemampuan boron yang dapat meningkatkan proses fotosintesis melalui perannya dalam metabolisme karbohidrat dan protein dalam tanaman. Hal inilah yang menyebabkan hasil polong kacang dengan penambahan boron dalam berbagai dosis menunjukan peningkatan berat, yang berarti biji kacang tanah menjadi lebih bernas.

Tabel 8. Berat $100 \mathrm{Biji}$

\begin{tabular}{lcccc}
\hline Perlakuan & 1 & 2 & 3 & Rata-rata \\
\hline A0 & 74,14 & 73,86 & 74,71 & $74,23 \mathrm{a}$ \\
A1 & 79,20 & 78,36 & 79,55 & $79,03 \mathrm{c}$ \\
A2 & 77,17 & 77,48 & 76,64 & $77,09 \mathrm{~b}$ \\
A3 & 79,83 & 78,14 & 77,66 & $78,54 \mathrm{c}$ \\
\hline
\end{tabular}

\section{Kandungan Minyak}

Kandungan minyak di dalam tanaman umumnya berbentuk sebagai lemak nabati. Hasil uji analisis kadar lemak (Gambar 2) menunjukan AO sebesar $29,26 \%$, A1 sebesar 33,61 \%, dan A2 36,37\%. Uji pemberian boron terhadap kandungan minyak kacang tanah memberikan pengaruh sangat nyata yang berimbas pada peningkatan terhadap kandungan lemak yang ada di dalam tanaman. Hasil ini menunjukan boron mampu meningkatkan metabolisme sekunder yang akhirnya berpengaruh pada peningkatan kandungan minyak di dalam kacang tanah. Hasil antar perlakuan juga cukup signifikan dalam peningkatan persentase lemak nabati namun dengan rentang yang menurun. Sampel A3 tidak dapat diuji untuk mengetahui kandungan lemaknya dikarenakan sampel rusak, namun diduga kandungan minyak pada sampel A3 juga turut meningkat.

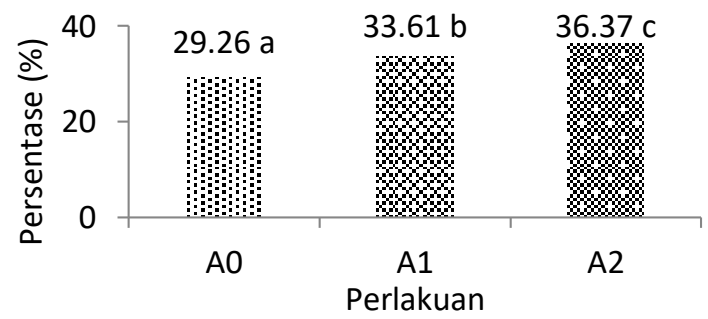

Gambar 2. Hasil kandungan lemak kacang tanah

\section{KESIMPULAN DAN SARAN}

Pengaplikasian Boron berpengaruh terhadap kualitas biji dengan adanya peningkatan pada bobot dan kandungan lemak biji kacang tanah.

\section{DAFTAR PUSTAKA}

Matas MA, Gonzales-Fontes A, Camacho JJC. 2009. Effect of boron supply on nitrate concentration and its reduction in roots and leaves of tobacco plants. Biologia Plantarum 53 (1): 120-124.

Mattiello EM, Ruiz HA, Silva IR, Barros NF, Neves JCL, Behling M. 2009. Transporte de boro no solo e sua absorção por eucalipto. Revista Brasileira de Ciências do Solo. 33, 1281-1290.

Moura JZ, Prado RM, Benvindo RN, Chaves AL. 2013. Applying boron to coconut palm plants: effects on productivity boron to coconut palm trees. J Soil Sci Plant Nutri 2013, 13(1): 79-85.

Prado RM. 2008. Nutrição de plantas. 1. ed. São Paulo: Editora UNESP, page 407. 